\title{
First record of Amphipolycotyle chloroscombrus Hargis, 1957 (Monogenea, Polyopisthocotylea, Gastrocotylidae) in the South Atlantic Ocean
}

\author{
Eudriano F. S. Costa ${ }^{1 *}$, Sathyabama Chellappa ${ }^{2}$ \\ ${ }^{1}$ Programa de Pós-Graduação em Oceanografia do Instituto de Oceanografia da Universidade de São Paulo. \\ (Praça do Oceanográfico, 191, CEP: 05508-900, São Paulo, SP, Brazil). \\ ${ }^{2}$ Universidade do Rio Grande do Norte. \\ (Praia de Mãe Luiza, Via Costeira, Via Costeira, s/n, CEP: 59014-100, Natal, RN, Brazil). \\ *Corresponding author: eudriano@usp.br
}

Monogeneans are a group of largely ectoparasitic members of the phylum Platyhelminthes. These worms are considered to be among the most host-specific parasites in fish, commonly found on fins, body skin, gills, gill chambers, buccal cavity, cornea and nostrils of their host (BUCHMANN et al., 2004). However, the monogenean Polyopisthocotylea are generally found attached to the gill filaments of their hosts in all the seas of the world, occurring from littoral zones to open oceanic waters, from the poles to the tropics, and from surface waters to the depths of the sea (ROHDE, 2005). They have high host specificity, containing the greatest number of species in the group of marine parasites (LAMBERT, 1990; WILLIAMS JÚNIOR; BUNKLEY-WILLIAMS, 1996; BUSH et al., 2001; ROHDE, 2005).

Chloroscombrus chrysurus (LINNAEUS, 1766) (Osteichthyes: Carangidae), commonly known as the Atlantic bumper, has a wide distribution range in the tropical coastal region where it can reach $30 \mathrm{~cm}$ in total length. In the Western Atlantic there are records of this species from Massachusetts, USA, to Northern Argentina (MENEZES; FIGUEIREDO, 1980). The distribution of juveniles and adults occurs from coastal waters to depths of $200 \mathrm{~m}$, with schoolings inhabiting mostly shallow waters (both marine and estuarine areas) and mangrovelined lagoons (WEISS et al., 1976; CARPENTER, 2002). The occurrence of ectoparasites on C. chrysurus from the Brazilian coast line has been reported by CARVALHOSOUZA et al. (2009); COSTA et al. (2010); COSTA and CHELLAPPA (2010) and LIMA et al. (2013).

This study reports on the occurrence of the parasite Amphipolycotyle chloroscombrus on the host Chloroscombrus chrysurus (LINNAEUS, 1766) (Osteichthyes, Carangidae) captured in the coastal waters of Rio Grande do Norte, Brazil, and is the first recorded finding in the South Atlantic Ocean.

http://dx.doi.org/10.1590/S1679-87592016098406401
Samples of Atlantic bumper, C. chrysurus, were netted in the coastal waters of Rio Grande do Norte, northeastern region of Brazil (Figure 1). The fish were captured on a monthly basis, with the help of local fishermen using a beach seine, from January to December 2006 (COSTA et al., 2010; COSTA; CHELLAPA, 2010). After capture, the branchial filaments of each fish were examined for gill parasites. The parasites found were carefully removed and fixed in 5\% formaldehyde solution following the methodology proposed by EIRAS et al. (2006). The parasites were identified following HARGIS (1957). The identification was made based on the main characteristics of the species which distinguish it from all other genera belonging to the family Gastrocotylidae, such as (1) the general body shape with the opisthaptor as two unequal, posterior, lateral flanges; (2) different types of clamps in two opposite clamp rows one row being open and sessile, the other closed and pedunculated, and (3) the nature of the cirrus armament. The parasitological indices (prevalence, intensity and abundance) were calculated following BUSH et al. (1997). Chi-square test $\left(\chi^{2}\right)$, at the significance level of 0.05 , was applied to compare the number of males and females of $C$. chrysurus, as well as the parasitological indices between males and females of the host.

During the study period a total of 203 specimens of $C$. chrysurus were captured. Of this total, 136 were males and 67 females $\left(\chi^{2}=23.45, p<0.05\right)$. The size and weight of males and females ranged from 8.1 to $26 \mathrm{~cm}(14.8 \pm 3.03)$ TL and 5.8 to $134.8 \mathrm{~g}(31.6 \pm 18.0)$ in weight, respectively. A total of 46 parasites were collected from the gill filaments. A specimen of C. chrysurus and A. chloroscombrus are shown in Figure 2. Of the total number of fish sampled, 32 were infected by A. chloroscombrus (15.8\%). A mean intensity of 1.44 parasites per host and abundance of 0.23 parasites per fish sampled were registered. The parasitological indices did not differ significantly between males and females of C. chrysurus (Table 1). 


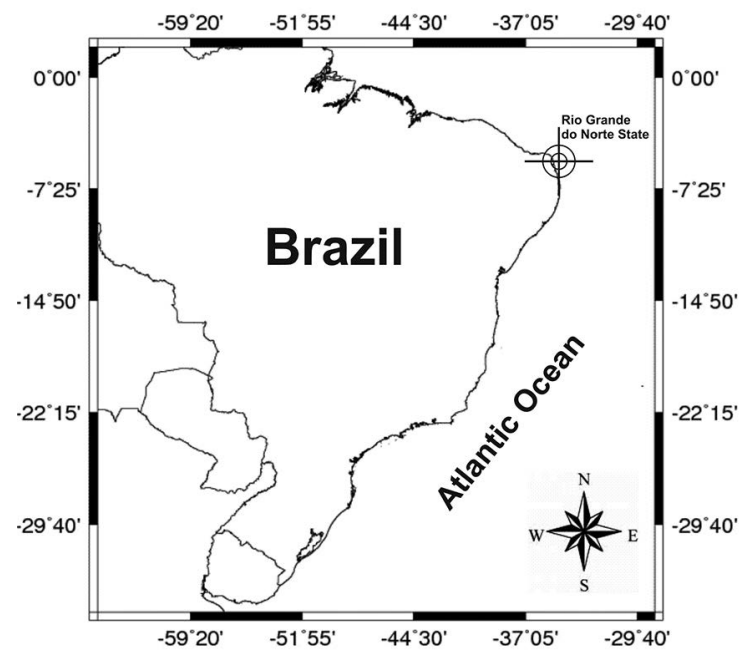

Figure 1. Sampling area: Rio Grande do Norte State, Brazil.
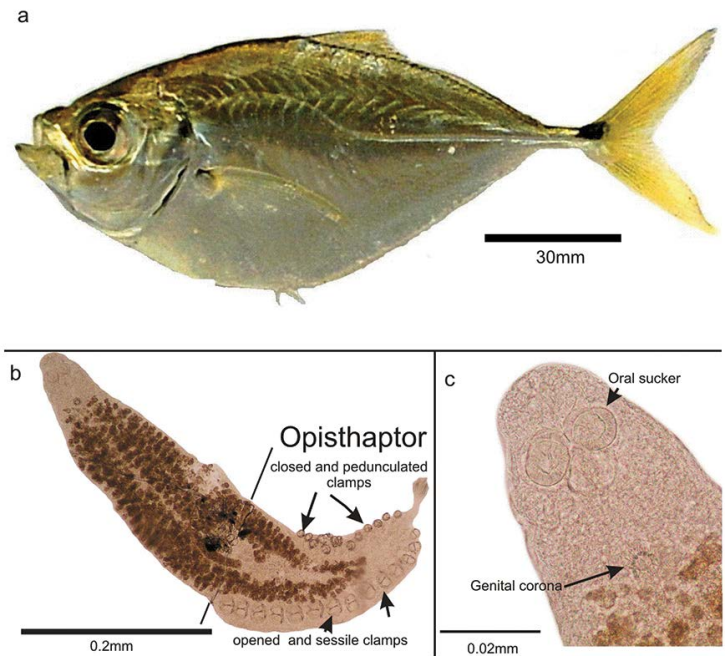

Figure 2. Specimen of Chloroscombrus chrysurus (a) and the ventral view of the gill parasite Amphipolycotyle chloroscombrus (bc).

The present study reports, for the first time, the occurrence of $A$. chloroscombrus on C. chrysurus in the South Atlantic Ocean, Brazil. So far, the occurrence of this parasite has been registered in the North Atlantic Ocean on the gill filaments of the host C. chrysurus (BRAVO-HOLLIS, 1984) and C. orqueta (LAMOTHE-ARGUMEDO et al., 1997) in Mexican waters. The monogenea Polyopisthocotylea, such as A. chloroscombrus, has high host specificity and its distribution tends to correspond closely to the distribution and migratory ability of their hosts (ROHDE, 2005).

Levels of infestation by monogenean gill parasites (Polyopisthocotylea), ranging from $8.7 \%$ to $81 \%$, have been reported for fishes inhabiting marine and estuarine ecosystems (Table 2). According to ROHDE (2005), large hosts represent potential habitats with greater resources for parasites than smaller ones, thus being able to support high rates of infestation. Moreover, environmental factors such as temperature and salinity which influence the reproduction of the monogeneans also affect their abundance and occurrence in some areas during the year (ERNST et al., 2005; LUO; YANG, 2010; KHIDR et al., 2012). Therefore, the low prevalence of $A$. chloroscombrus on C. chrysurus must be attributed to the reproductive cycle of the parasite and/or the influences of environmental factors, as has also been reported by MUÑOZ and RANDAHAWA (2011) and ÖZER and KIRCA (2013) (Table 2).

In some cases, the differences between the numbers of male and female fish parasitized can be related to the comparative physiological conditions of the sexes of hosts. Accordingly, ROHDE (1984) reported that sometimes one of the host sexes is more vulnerable than the other. Although the male specimens predominated in the sampled population of $C$. chrysurus, the infection caused by A. chloroscombrus was similar in both sexes, corroborating the results published by LUQUE et al. (1996) and AZEVEDO et al. (2007), who found no relationship between the prevalence of metazoan parasites, including monogenea, and their hosts.

Table 1. Parasitological indices of the gill parasite Amphipolycotyle chloroscombrus, mean ( \pm standard deviation), minimum and maximum values of the total length and weight of the hosts Chloroscombrus chrysurus. The results of the chi-squared test $\left(\chi^{2}\right)$ applied to compare the parasitological sex ratio are also given.

\begin{tabular}{lccccc}
\hline & Both sexes & Males & Females & $\chi^{2}$ & $p$-value \\
\hline Prevalence (\%) & 15.8 & 9.9 & 5.9 & 1.01 & 0.31 \\
Intensity* & 1.44 & 1.00 & 2.17 & 0.43 & 0.51 \\
Abundance** & 0.23 & 0.10 & 0.13 & 0.00 & 0.95 \\
Total length (cm) & $14.5 \pm 3.1$ & $14.0 \pm 3.3$ & $15.4 \pm 2.5$ & & \\
Total weight (g) & $32.7 \pm 16.8$ & $30.0 \pm 17.3$ & $37.3 \pm 15.4$ & & \\
\hline
\end{tabular}

* Number of parasites per host. ** Number of parasites per fish sampled. 
Table 2. Prevalence of monogenean parasites (Polyopisthocotylea) in the gills of fishes sampled in different ecosystems

\begin{tabular}{|c|c|c|c|c|}
\hline Region & Host & Parasite & Prevalence (\%) & Authors \\
\hline Coastal waters of Peru & $\begin{array}{l}\text { Cheilodactylus variegatus } \\
\text { (Cheilodactylidae) }\end{array}$ & $\begin{array}{l}\text { Microcotyle } \\
\text { nemadactylus }\end{array}$ & $75 \%$ & Oliva and Luque (1998) \\
\hline $\begin{array}{l}\text { Coastal waters of Rio de } \\
\text { Janeiro State }\end{array}$ & $\begin{array}{l}\text { Peprilus paru } \\
\text { (Stromateidae) }\end{array}$ & Microcotyle sp. & $81 \%$ & Azevedo et al. (2007) \\
\hline $\begin{array}{l}\text { Segara Anakaran Lagoon, } \\
\text { Indonesia }\end{array}$ & $\begin{array}{l}\text { Eleutheronema tetradac- } \\
\text { tylum (Polynemidae) }\end{array}$ & M. polinemi & $67 \%$ & Rueckert et al. (2009) \\
\hline $\begin{array}{l}\text { Rocky shores of El Tabo, } \\
\text { Chile }\end{array}$ & $\begin{array}{l}\text { Scartichthys viridis } \\
\quad \text { (Blenniidae) }\end{array}$ & Mcrocotyle sp. & $18.4 \%$ & $\begin{array}{l}\text { Muñoz and Randhawa } \\
\text { (2011) }\end{array}$ \\
\hline $\begin{array}{l}\text { Kizilirmak Delta in Samsun, } \\
\text { Turkey }\end{array}$ & Liza aurata (Mugilidae) & M. mugilis & $8.7 \%$ & Özer and Kirca (2013) \\
\hline $\begin{array}{l}\text { Coastal waters of Rio Grande } \\
\text { do Norte }\end{array}$ & $\begin{array}{c}\text { Chloroscombrus chrysurus } \\
\text { (Carangidae) }\end{array}$ & $\begin{array}{l}\text { Amphipolycotyle } \\
\text { chloroscombrus }\end{array}$ & $15.8 \%$ & Present study \\
\hline
\end{tabular}

\section{ACKNOWLEDGEMENTS}

This study was supported by the National Council for Scientific and Technological Development of Brazil (CNPq) in the form of Research grants to E. F. S. Costa (Grant $\left.n^{\circ} .1059892005-3\right)$ and S. Chellappa. Our thanks are due to Dr. José Luis Fernando Luque Alejos of the Universidade Federal Rural do Rio de Janeiro (UFRRJ) for the taxonomical identification of the parasite.

\section{REFERENCES}

AZEVEDO, R. K.; ABDALLAH, V. D.; LUQUE, J. L. Aspectos quantitativos da comunidade de metazoários parasitos do gordinho Peprilus paru (Linnaeus, 1758) (Perciformes: Stromateidae), do litoral do estado do Rio de Janeiro, Brasil. Rev. Bras. Parasitol. Vet., v. 16, n. 1, p. 10-14, 2007.

BRAVO-HOLLIS, M. Monogenean of fishes from the Gulf of Mexico and Caribbean. X. New localities for six known species. An. Inst. Biol. Zool. Univ. Nac. Auton. Méx., v. 55, n. 1, p. 61-71, 1984.

BUSH, A. O.; LAFFERTY, K. D.; LOTZ, J. M.; SHOSTAK, A. W. Parasitology meets ecology on its own terms: Margolis et al. revisited. J. Parasitol., v. 83, n. 4, p. 575-583, 1997.

BUSH A. O.; FERNÁNDEZ J. C.; ESCH G. W.; SEED, J. R. Parasitism: the diversity and ecology of animal parasites. Cambridge: Cambridge University Press, 2001. 580 p.

BUCHMANN, K.; LINDENSTRØM, T.; BRESCIANI, J. Interactive associations between fish hosts and monogeneans. In: WIEGERTJES, G. F.; FLIK, G., Eds. Host-parasite interactions. Milton Park: BIOS Scientific Publishers, 2004. p. 161184.

CARPENTER, K. E. The living marine resources of the western central Atlantic: Bony fishes parte 2 (Opistognathidae to Molidae), sea turtles and marine mammals. Rome: Food and Agriculture Organization of the United Nations, 2002. p. 1375-2127.

CARVALHO-SOUZA, G. F.; SOUZA NETO, J. R.; ALELUIA, F. T.; NASCIMENTO, I. A.; BROWNE-RIBEIRO, H.; SANTOS, R. C.; TINÔCO, M. S. Occurrence of isopods ectoparasites in marine fish on the Cotegipe Bay, north-eastern Brazil. Mar. Biodivers. Rec., v. 2, p. 1-4, 2009.
COSTA, E. F. S.; OLIVEIRA, M. R.; CHELLAPPA, S. First record of Cymothoa spinipalpa (Isopoda: Cymothoidae) parasitizing the marine fish Atlantic bumper, Chloroscombrus chrysurus (Osteichthyes: Carangidae) from Brazil. Mar. Biodivers. Rec., v. 3, p. 1-6, 2010.

COSTA, E. F. S.; CHELLAPPA, S. New host record for Livoneca redmanni (Leach, 1818) (Isopoda: Cymothoidae) in the Brazilian coastal waters with aspects of host-parasite interaction. Braz. J. Oceanogr., v. 58, n. 4, p. 73-77, 2010.

EIRAS, J. C.; TAKEMOTO, R. M.; PAVANELLI, G. C. Métodos de estudo e técnicas laboratoriais em parasitologia de peixes. 3a. ed. Maringá: EDUEM, 2006. 199 p.

ERNST, I.; WHITTINGTON, I. D.; CORNEILLIE, S.; TALBOT, C. Effects of temperature, salinity, desiccation and chemical treatments on egg embryonation and hatching success of Benedia seriolae (Monogenea: Capsalidae), a parasite of farmed Seriola spp. J. Fish Dis., v. 26, n. 3, p. 157-164, 2005.

HARGIS JÚNIOR, W. J. Monogenetic trematodes of Gulf of Mexico fishes. Part XIII. The family gastrocotylidae Price, 1943 (Continued). Trans. Am. Microsc. Soc., v. 76, n. 1, p. 1-12, 1957.

KHIDR, A. A.; SAID, A. E.; SAMAK, O. A.; ABU SHEREF, S. E. The impacts of ecological factors on prevalence, mean intensity and seasonal changes of the monogeneans gill parasite, Microcotyloides sp., infesting the Terapon puta fish inhabiting coastal region of the Mediterranean Sea at Damietta region. J. Basic Appl. Zool., v. 65, n. 2, p. 109-115, 2012.

LAMOTHE-ARGUMEDO, R.; GARCÍA-PRIETO, L.; D. OSORIO-SARABIA, D.; PÉREZ-PONCE DE LEÓN, G. Catálago de La Colección Nacional de Helmintos. Mexico City: Universidade Nacional Autonoma de México, 1997. 211 p.

LAMBERT, A. Environment and host-parasite relationships in monogenea. Folia Parasit., v. 37, n. 3, p. 219-224, 1990.

LIMA, J. T. A. X.; CHELLAPPA, S.; THATCHER, V. E. Livoneca redmanni Leach (Isopoda, Cymothoidae), Rocinela signata Schioedte \& Meinert (Isopoda, Aegidae), ectoparasitos de Scomberomorus brasiliensis Collete, Russo \& Zavala-Camin (Ostheichthyes, Scombridae) no Rio Grande do Norte, Brasil. Rev. Bras. Zool., v. 22, n. 4, p. 1104-1108, 2005.

LIMA, J. T. A. X.; COSTA, E. F. S.; NASCIMENTO, W. S.; CHELLAPPA, S. Tendências evolutivas do parasito Livoneca redmanni Leach, 1818 (Crustacea, Isopoda, Cymothoidae) em duas espécies de peixes marinhos do Rio Grande do Norte, Brasil. Bio. Amaz., v. 3, n. 1, p. 66-73, 2013. 
LUO, Y. F.; YANG, T. B. Seasonal population dynamics of the monogeneans Pseudorhabdosynochus coioidesis and $P$. serrani on wild versus cultured groupers in Daya Bay, South China Sea. Helmintologia, v. 47, n. 4, p. 241-250, 2010.

LUQUE, J. L.; AMATO, J. F. R.; TAKEMOTO, R. M. Comparative analysis of the communities of metazoan parasites of Orthopristis ruber and Haemulon steindachneri (Osteichthyes: Haemulidae) from the southeastern Brazilian littoral: I. Structure and influence of the size and sex of hosts. Rev. Bras. Biol., v. 56, p. 279-292, 1996.

MENEZES, N. A.; FIGUEIREDO, J. L. Manual dos Peixes Marinhos do Sudeste do Brasil IV, Teleostei (3). São Paulo: Museu de Zoologia, 1980. 96 p.

MUÑOZ, Z.; RANDHAWA, H. S. Monthly variation in the parasite communities of the intertidal fish Scartichthys viridis (Blenniidae) from central Chile: are there seasonal patterns? Parasitol. Res., v. 109, n. 1, p. 53-62, 2011.

OLIVA, M. E.; LUQUE, J. L. Distribution patterns of Microcotyle nemadactylus (Monogenea) on gill filaments of Cheilodactylus variegatus (teleostei). Mem. Inst. Oswaldo Cruz, v. 93, n. 4, p. 477-478, 1998.
ÖZER, A.; KIRCA, D. Y. Parasite fauna of Golden Grey Mullet Liza aurata (Risso, 1810) collected from Lower Kizilirmak Delta in Samsun, Turkey. Helmintologia, v. 50, n. 4, p. 269280, 2013.

ROHDE, K. Zoogeography of marine parasites. Helgol. Meeresun., v. 37, n. 1, p. 35-52, 1984.

ROHDE, K. Marine parasitology. Melbourne: CAB Publishing, $2005.565 \mathrm{p}$.

RUECKERT, S.; HAGEN, W.; YUNIAR, A. T.; PALM, H. W. Metazoan fish parasites of Segara Anakaran Lagoon, Indonesia, and their potential use as biological indicators. Reg. Environ. Change, v. 9, n. 4, p. 315-328, 2009.

WEISS, G.; FEIJO-SOUZA, J. A.; SANTOS, A. Contribution of the knowledge of the marine ichthyoplankton on southern shelf of Brazil. Atlântica, v. 1, n. 1/2, p. 79-99, 1976.

WILLIAMS JÚNIOR, E. H.; BUNKLEY-WILLIAMS, L. Parasites of offshore big game fishes of Puerto Rico and the Western Atlantic. San Juan: Department of Biology, University of Puerto Rico, 1996. 384 p. 